\title{
Analisis Pemikiran al-Tafsir al-Maudlu'i al-Tauhidi Baqir Al-Shadr
}

\section{Analysis of Baqir Al-Shadr's Thought of al-Tafsir Al-Maudlu'i Al-Tauhudi}

\author{
Aramdhan Kodrat Permana \\ Sekolah Tinggi Agama Islam (STAI) Syamsul Ulum Gunung Puyuh \\ Sukabumi, Jawa Barat, Indonesia \\ aramdhankodratpermana14@gmail.com
}

\begin{abstract}
Abstrak
Tafsir al-Maudlu'i al-Tauhidi dikenalkan oleh Baqir al-Shadr. Kajian ini bertujuan untuk menganalisis pemikiran al-Al-Tafsir al-Maudlu'i-AlTauhidi Baqir Al-Shadr. Penelitian ini menggunakan pendekatan kualitatif berdasarkan pada kajian kepustakaan dan bersumber dari prime resource karya Baqir al-Shadr, al-Madrasat al-Qur'aniyyah, dengan bahan sekundernya dari pemikiran al-Farmawi dan bahan lain yang relevan. Penyajian kajian ini bersifat deskriptif-analitik yang digabungkan dengan teori korespondensi terutama ketika menguji secara kritis teori dan aplikasi konsep Baqir al-Shadr. Berdasarkan kajian, dengan dasar min al-Waqi ila al-Nash, Baqir al-Shadr menyatakan bahwa tafsir maudlu'i harus mampu berdialektika dengan fakta serta teori yang berkembang saat ini tanpa melepaskan langkah-langkah metodologis tafsir maudlu'i yang telah dirumuskan sebelumnya, seperti memerhatikan bahts al-Mufradat, asbab al-Nuzul dan makkiyyah-madaniyyah. Dengan teori korespondensi yang diaplikasikan pada kajian kritis teori dan aplikasinya, Baqir al-Shadr nampak belum melakukan secara konsisten dan komprehensif teori yang ia bangun.
\end{abstract}

Kata Kunci: al-Tafsir al-Maudlu'i al-Tauhidî, Baqir al-Shadr, min al-Nash ila al-Waqi.

\section{Abstract}

Tafsir al-Maudlu'i al-Tauhidi introduced by Baqir al-Shadr. This study aims to analyze the thoughts of al-Al-Tafsir al-Maudlu'i-Al-Tauhidi Baqir Al-Shadr. This study used a qualitative approach based on literature review and sourced from prime resources by Baqir al-Shadr, al-Madrasat al-Qur'aniyyah, with secondary materials from al-Farmawi thought and other relevant materials. This research presents descriptive-analytic combined with correspondence theory, especially when critically examining the theory and application of the concept of Baqir al-Sadr. Based on the study, by the basis of min al-Nash ila al-Waqi he stated that 
tafsir maudlu'i has to mutual dialect with the reality and its developing theories without releasing the classical Qur'anic steps in tafsir maudlu'i such bahts al-Mufradat, asbab al-Nuzul and makkiyyah-madinyyah theory. In the end, by using the correspondence theory which applied on critical study of his theory and application, it seems that Baqir al-Shadr himself had not applied his theory on his quranic topical interpretation.

Keywords: al-Tafsir al-Maudlu'i al-Tauhidî, Baqir al-Shadr, min al-Nash ila al-Waqi.

\section{PENDAhULUAN}

Tafsir sebagai upaya manusia untuk memahami kalamullah dalam sejarah keislaman mengalami perkembangan yang signifikan (Permana, 2020), baik itu dari isi, corak dan metodologi. Dari sisi metodologis tafsir bergerak dari metode periwayatan, naqli, sampai nuzuli dan maqasidi. Fakta ini merupakan konsekuensi logis dari harakah muhtawa atau alahwal al-mutaghayirah, faktor eksternal teks yang selalu berubah dan bergerak, dan penafsir adalah subyek utamanya.

Tafsir maudhu'i adalah salah satu metode tafsir yang muncul di awal abad ke-20. Tafsir ini dimunculkan secara terminologis dan metolodogis oleh Abu Hayy al-Farmawi. Di Indonesia ia secara langsung diperkenalkan oleh Quraish Shihab dalam bukanya Wawasan
al-Qur'an. Sejak itu tafsir ini menjadi perbincangan akademik dan kajian khusus di kalangan akademi IAIN/UIN. Tafsir ini meniscayakan gerakan tafsir yang mempertimbangkan kesatuan tema al-Qur'an tertentu. Sehingga dengan jenis tafsir ini seseorang mampu memahami al-Qur'an secara holistik dalam masalah tertentu. Namun oleh beberapa sarjana tafsir ala al-Farmawi ini masih berkonsentrasi pada teks, walaupun variabel asbab nuzûl masuk dalam langkah metodis tafsirnya. Sehingga dilihat tidak mampu melihat realitas yang sebenarnya terjadi. Pada titik inilah seorang Baqi al-Shadr memperkenalkan konsepnya, alTafsir al-Tauhidi. Sebuah tafsir yang bergerak dari realitas menuju teks. Sehingga teks mampu memberikan solusi terbaik pada realitas yang terjadi. Dari sinilah kemudian penulis mengkaji secara 
singkat konsep tafsirnya berserta contoh aplikasinya.

\section{METODE PENELITIAN}

Penelitian kualitatif adalah penelitian yang akan dijadikan dasar metode penelitian ini dengan berdasarkan pada kajian kepustakaan dan bersumber dari prime resource karya Baqir alShadr, al-Madrasat alQur'aniyyah. Pada bahan sekundernya, pemikiran alFarmawi akan menjadi pembanding. Penyajian makalah ini bersifat deskriptif-analitik yang digabungkan dengan teori korespondensi terutama ketika menguji secara kritis teori dan aplikasi konsep Baqir al-Shadr.

Kajian pemikiran Baqir alShadr ini tentu bukan yang pertama. Banyak kajian yang berbentuk makalah, tesis bahkan disertasi yang membahas tentang Baqir al-Shadr, semisal tesis yang disusun oleh Lailia Muyasaroh, "Epistemologi Tafsir Syi'i: Studi Atas Hermeneutika al-Qur'an Muhammad Baqir al-Shadr" tahun 2019 di UIN Sunan Kalijaga dan tesis yang disusun oleh M Wiyono dengan judul "Paradigma Penafsiran Dari Realitas Menuju Teks: Studi Aplikatif Manhaj
Tawhidi Baqir al-Shadr" tahun 2019 di UIN Syarif Hidayatullah.

Walaupun demikian kajian singkat yang dilakukan penulis lebih menitikberatkan pada paparan teoretis dan aplikatif secara ringkas-komprehensif tentang konsep al-Tafsir alTauhidi Baqir al-Shadr.

III. HASIL

DAN PEMBAHASAN

\section{A. Al-Al-Tafsir Al-Maudlu'i dalam Realitas Sejarah}

1. Definisi al-Al-Tafsir alMaudlu'i

Kata maudlu' $i$ merupakan isim maf'ul dari fi'il al-Madli wadla'a yang berarti meletakkan, menjadikan, mendustakan dan membuat-buat.

Arti maudlu' $i$ yang dimaksud di sini ialah yang dibicarakan atau judul atau topik atau sektor, sehingga al-al-Tafsir alMaudlu'i berarti penjelasan ayatayat Al-Qur'an mengenai satu judul/topik/sektor pembicaraan tertentu dan bukan maudlu' $i$ yang berarti yang didustakan atau dibuat-buat, seperti arti kata hadis maudlu' yang berarti hadis yangdidustakan/ dipalsukan/ dibuat-buat (Jalal, 1990). 
Adapun pengertian al-Tafsir al-Maudlu' $i$ (tematik) menurut istilah para ulama ialah:

"Mengumpulkan ayat-ayat alQur'an yang membahas tentang satu judul/topik/sektor tertentu dan menertibkannya semampu mungkin sesuai dan selaras dengan masa turun dan asbabnya, kemudian memperhatikan ayatayat tersebut dengan penjelasanpenjelasan, keteranganketerangan dan hubunganhubungannya dengan ayat-ayat lain, kemudian mengintisarikannya." (Abu Hayy al-Farmawy, 1968).

Mursyi Ibrahim al-Fayumi (1980) membagi metode ini menjadi dua yaitu pertama, tafsir surah, yaitu menjelaskan suatu surah secara keseluruhan dengan menjelaskan isi kandungan surah tersebut, baik yang bersifat umum atau khusus dan menjelaskan keterkaitan antara tema yang satu dengan yang lain, sehingga surah itu nampak merupakan suatu pembahasan yang sangat kokoh dan cermat. Kedua, tafsir tematik, yaitu menghimpun sejumlah ayat al-Qur'an yang memiliki kesamaan tema dan kemudian membahasnya secara mendetail.
Senada dengan al-Fayumi, Quraish Shihab mengatakan bahwa

metode maudlu'i mempunyai dua pengertian. Pertama, penafsiran menyangkut satu surat dalam alQur'an dengan menjelaskan tujuan-tujuannya secara umum dan yang merupakan tema ragam dalam surat tersebut antara satu dengan lainnya dan juga dengan tema tersebut, sehingga satu surat tersebut dengan berbagai masalahnya merupakan satu kesatuan yang tidak terpisahkan. Kedua, penafsiran yang bermula dari menghimpun ayat-ayat alQur'an yang dibahas satu masalah tertentu dari berbagai ayat atau surat al-Qur'an dan sedapat mungkin diurut sesuai dengan urutan turunnya, kemudian menjelaskan pengertian menyeluruh ayat-ayat tersebut, guna menarik petunjuk al-Qur'an secara utuh tentang masalah yang dibahas itu. Lebih lanjut M. Quraish Shihab mengatakan bahwa, dalam perkembangannya metode maudlu' $i$ memiliki dua bentuk penyajian. Pertama menyajikan kotak berisi pesanpesan al-Qur'an yang terdapat pada ayat-ayat yang terangkum 
pada satu surat saja. Biasanya kandungan pesan tersebut diisyaratkan oleh nama surat yang dirangkum padanya selama nama tersebut bersumber dari informasi rasul.

Kedua, metode maudlu'i mulai berkembang tahun 60 -an. Bentuk kedua ini menghimpun pesanpesan al-Qur'an yang terdapat tidak hanya pada satu surah saja.

2. Sejarah perkembangan AlTafsir al-Maudlu'i

Dasar-dasar al-Tafsir alMaudlu' $i$ telah dimulai oleh Nabi SAW sendiri yaitu dengan penafsiran ayat dengan ayat. Hal ini dipertegas oleh al-Farmawi bahwa semua penafsiran ayat dengan ayat bisa dipandang sebagai al-Tafsir alMaudlu'i dalam bentuk awal (alFarmawi, 1977). Menurut Quraish Shihab, tafsir tematik berdasarkan surah digagas pertama kali oleh seorang guru besar jurusan Tafsir, fakultas Ushuluddin Universitas al-Azhar, Syaikh Mahmud Syaltut, pada Januari 1960. Karya ini termuat dalam kitabnya, Tafsir al-Qur'an al-Karim. Sedangkan al-Tafsir alMaudlu'i berdasarkan subjek digagas pertama kali oleh Ahmad
Sayyid al-Kumiy, seorang guru besar di institusi yang sama dengan Mahmud Syaltut, jurusan Tafsir, fakultas Ushuluddin Universitas al-Azhar, dan menjadi ketua jurusan Tafsir sampai tahun 1981. Model tafsir ini digagas pada tahun 1960-an. Buah dari tafsir model ini menurut Quraish Shihab di antaranya adalah karyakarya Abbas Mahmud alAqqad,al-Insân fì al-Qur'ân,alMar'ah fì al-Qur'ân, dan karya Abul A'la al-Maududi, al-Ribâ fí al-Qur'ân.

Kemudian tafsir model ini dikembangkan dan disempurnakan lebih sistematis oleh Prof. Dr. Abdul Hay al-Farmawi, pada tahun 1977, dalam kitabnya al-Bidayah fi al-Tafsir al-Maudu ' $i$ : Dirasah Manhajiyah

Maudu'iyah. Namun jika, merujuk pada catatan lain, kelahiran tafsir tematik jauh lebih awal dari apa yang dicatat Quraish Shihab, baik tematik berdasar surah maupun berdasarkan subjek.

Kaitannya dengan tafsir tematik berdasar surah al-Qur'an, Burhanuddin al-Zarkashi (w. 745$794 \mathrm{H} / 1344-1392 \mathrm{M})$, dengan karyanya al-Burhân fi 'Ulûm alQur'ân, adalah salah satu contoh 
tokoh paling awal yang menekankan urgensi tafsir dengan bahasan surah demi surah. Demikian juga Suyûtî (w. 911 H/1505 M) dalam karyanya alItqân fì 'Ulûm al-Qur'ân. Sementara tematik berdasar subyek, diantaranya adalah karya Ibn Qayyim al-Jauzîyah (12921350 M.), ulama besar dari mazhab Hanbalî, yang berjudul alBayân fî̀ Aqsâm al-Qur'ân; Majâz al- Qur'ân oleh Abû 'Ubaid ; Mufradât al-Qur'ân oleh alRâghib al-Isfahânî; Asbâb alNuzûl oleh Abû al-Hasan alWahîdî al-Naisâbûrî （w. 468 H/1076 M).

Oleh sebab itu secara historis tafsir tematik sudah diperkenalkan sejak sejarah awal tafsir. Lebih jauh, perumusan konsep ini secara metodologis dan sistematis berkembang di masa kontemporer. Demikian juga dengan jumlahnya semakin bertambah di awal abad ke 20, baik tematik berdasarkan surah alQur'an maupun tematik berdasar subyek/topik.

Di sisi yang lain dalam pandangan Al-Farmawy (1968), pencetus dari metode tafsir ini adalah Muhammad Abduh yang kemudian ide-ide pokoknya dikembangkan oleh Mahmud Syaltut dan diintroduksikan secara kongrkrit oleh Sayyid Ahmad Kamal al-Kumi. Al-Kumi mengintroduksikan metode tafsir jenis ini dalam bukunya yang berjudul Al-Tafsir al-Maudlu'i. Mengenai tafsir ini al-Kumi, yang selanjutnya dikutip oleh Dr. Ali Hasan al-'Aridl, mengatakan:

"Era dimana kita hidup adalah era ilmu dan kebudayaan; era yang membutuhkan kepada metode maudlu' $i$ yang dapat mengantarkan kita untuk sampai kepada suatu maksud dan hakekat suatu persoalan dengan cara yang paling mudah. Terlebih-lebih pada masa kita sekarang ini telah banyak bertaburan "debu-debu" terhadap hakekat agama-agama, sehingga tersebar-lah doktrindoktrin komunisme, atheisme dan lain-lain, serta "langit" kehidupan manusia telah dipenuhi oleh awan kesesatan dan kesamaran. Untuk menghadapi kondisi yang demikian ini, tidak ada lain kecuali harus dipergunakan suatu "senjata" yang kuat, jelas dan mudah, yang memungkinkan bagi tokoh-tokoh agama untuk membela "telaga-telaga" agama 
dan mempertahankan tiang-tiang agama. Persoalan itu tidak mungkin bisa diatasi kecuali dengan metode tafsir madlu'i yang dapat diterapkan untuk bermacam-macam tema dalam alQur'an dan meliputi segala hal (al-Farmawy, 1977)

\section{B. Min Al-Waqi Ila Al-Nash}

1. Konsep al-Tafsir al-Maudlu'i al-Tauhidi menurut Baqir alShadr

Dalam pandangan penulis pemahaman Baqir al-Shadr terhadap al-Qur'an, serta definisinya, tentu berpengaruh pada konsep tafsir yang ia sebuat sebagai tafsir tematik-tauhidi. AlQur'an menurut Baqir al-Shadr merupakan kitab ilahi yang diperuntukkan sebagai hidayah serta pembangunan nilai-nilai kemanusiaan. Hal ini tentunya mengingatkan pada pada awal abad-20 tentang pernyataan dari Muhammad 'Abduh bahwa alQur'an harus dikembalikan fungsinya sebagai hidayah. Baqir al-Shadr pun menjadikan nilainilai kemanusian sebagai pondasi awal untuk memahami al-Qur'an (Baqir al-Shadr, 2005: 39). Dalam konteks al-Tafsir al-Maudlu'i wajar jika ia menggunakan konsep min al-Waq'i ila al-Nash sebagai sebuah usaha untuk menjawab problematika kemanusiaan.

Baqir al-Shadr secara ringkas menjelaskan bahwa metode al-Tafsir al-Maudlu'i adalah metode tafsir yang berusaha mencari jawaban alQur'an dengan cara mengumpulkan ayat-ayat alQur'an yang mempunyai tema yang sama dan menertibkannya sesuai dan selaras dengan masa turun dan sebab-sebab turunnya, kemudian memperhatikan ayatayat tersebut dengan penjelasanpenjelasan, keteranganketerangan dan hubunganhubungannya dengan ayat-ayat yang lain. Pada akhirnya seorang mufassir mampu melakukan istinbath al-Ahkam (al-Shadr, 2005)

Dengan kata lain tafsir alTauhidi al-Maudhlu'i merupakan tafsir yang secara metodis tidak menafsirkan ayat per ayat sebagaimana al-Tafsir al-Tajzii atau tafsir tahlili. Karena dalam pandangan Baqir al-Shadr tafsir tematik berangkat dari tema-tema kehidupan manusia seperti kepercayaan, kemasyarakatan, dan yang lainnya (al-Shadr, 2005) 
Karena dalam pandangannya sebuah tafsir haruslah memberikan sebuah solusi dan itu tidak bisa muncul jika tidak ada dialektika antara problematika kehidupan dengan ayat-ayat alQur'an (al-Shadr, 2005).

Oleh sebab itu kajian-kajian ulama terdahulu seperti $a s b a b$ alNuzul, atau Qiraat, al-Nasikh wa al-Mansukh, Majazat al-Qur'an, sebagaimana angggapan sebagian para ulama, bukanlah termasuk alTafsir al-Maudlu'i al-Tauhidi. Menurutnya itu hanyalah kajian pengelompokan secara massal dari tafsir tahlili atau tajizi'i. Maka Baqir al-Shadr menegaskan bahwa tidak setiap aktivitas yang itu berorientasi pada pengumpulan ayat-ayat al-Qur'an adalah alTafsir al-Maudlu'i. Karena, sekali lagi, ia harus berangkat dari tematema kehidupan semisal teologi, sosial atau yang lainnya yang secara langsung disandingkan dengan ayat-ayat al-Qur'an (alShadr, 2005). Inilah mengapa ia selalu menegaskan bahwa realitas harus dibawa kedalam teks-teks al-Qur'an sehingga al-Qur'an bisa memberikan sosuli, min al-Nash ila al-Waq'i.
Adapun kenapa ia sinonimkan nama al-Maudlu'i dengan nama al-Tauhidi tiada lain karena dalam metode tafsir ini seorang mufassir harus bisa menyatukan ayat-ayat berserta maksud dan maknanya yang terkandung di dalam kumpulan ayat tersebut. Dus, istilah alMaudlu' $i$ dan istilah al-Tauhidi dalam konteks ini menyatu dan mempunyai kesamaan. Perbedaannya hanya terletak pada mekanisme pelaksanaannya. Jika al-Maudlu' $i$ adalah proses pengambilan tema sosial kepada al-Qur'an sedangkan al-Tauhidi adalah proses selanjutnya yang berorientasi pada pencarian makna setelah adanya aktivitas pengumpulan ayat-ayat tersebut (al-Shadr, 2005).

Baqir al-Shadr pun menyadari bahwa konsep maudlu' $i$-dalam persepektifnya terlebih dahulu dilakukan oleh ulama-ulama Fiqh. Akan tetapi itu pun tidak cukup karena harus dikembangkan dengan upaya integrasi antara teori-teori agama (baca: teologis) dengan teori sosial, dialektika vertikalhorizontal (al-Shadr, 2005). Walaupun tidak secara eksplisit 
menyebutkan kesetujuaan terhadap dialektika vertikalhorizontal sebagaimana yang ia sarankan pada ulama-ulama fiqh tetapi Baqir al-Shadr sadar bahwa hal itu pun harus dilaksanakan dalam konsep tafsir. Oleh sebab itu ia membuat pertanyaanpertanyaan mendasar sebagai pembuka al-Tafsir alMaudlu'inya, Apakah pentingnya menghasilkan teori-teori

keislaman? Lalu apa urgensi memahami teori-teori keislaman di dalam kenabian, misalnya, dalam konsep yang lebih umum?

Disisi lain ia pun menyadarai bahwa teori-teori Islam pun tidak cukup kecuali harus didialektikan secara horizontal dengan teori-teori Barat yang sekarang sudah marak. Walaupun tentunya akan terjadi banyak perbedaan. Disinilah posisi mufassir yang harus mampu, secara proporsional, mengambil madlul daripada kumpulan-kumpulan ayat. Karena hanya dari al-Qur'an-lah muncul teori-teori islam yang saat ini menjadi penting sebagai pembanding daripada teori Barat. Oleh sebab itu mufassir harus mampu mendalami teks-teks keagamaan, dalam hal ini salah satunya adalah al-Qur'an, untuk bisa membedakan mana yang baik dan tidak dari pada teori-teori yang berkembang pada saat ini (al-Shadr, 20052)

2. Langkah Metodis al-Tafsir alMaudlu'i

Sebagai seorang mufassir alFarmawi berhasil membuat sebuah langkah metodis dalam alTafsir al-Maudlu'i yang ia rangkum dalam 7 langkah, yang hal ini belum pernah dilakukan oleh para ulama sebelumnya;

“a) Menetapkan masalah yang akan dibahas, b) menghimpun seluruh ayat-ayat alQur'an yang berkaitan dengan tema yang hendak dikaji, baik makkiyah maupun madaniyyah, c) menentukan urutan-urutan ayat yang dihimpun itu sesuai dengan masa turunnya, disertai dengan pengetahuan asbab al-Nuzulnya, d) menjelaskan munasabah atau korelasi antara ayat-ayat itu pada masing-masing suratnya dan kaitannya ayat-ayat itu dengan ayat-ayat setelahnya, e) membuat sistematika kajian dalam kerangka yang sitematis dan lengkap dengan outlinenya yang mencakup semua segi dari tema 
kajian, f) mengemukakan hadishadis Rasulullah saw yang berbicara tentang tema kajian, g) mempelajari ayat-ayat tersebut secara keseluruhan, dan menyusun kesimpulan-kesimpulan yang menggambarkan jawban terhadap al-Qur'an terhadap masalah yang dibahas. (Baqir al-Shadr, 2005: 62)

Para ulama setelah alFarmawi, walaupun memiliki perbedaan dalam langkah metodis tafsir tematik tetapi masih merujuk pada al-Farmawi. Hal ini berbeda dengan langkah yang dilakukan oleh Baqir al-Shadr. Baginya menetapkan masalah bukan hanya dengan penyebutan sebuah tema tetapi bagaimana seorang mufassir mendalami secara obyektif permasalahan yang akan menjadi pembahasan dalam tafsir tematik.

Setelah tema penafsiran ditetapkan, seorang harus memosisikan dirinya sebagai peserta dialog aktif yang terus berusaha mengembangkan pelacakan ayat-ayat sehingga menjadi salah satu kesatuan konsep yang utuh (Arikunto, 2005). Langkah selanjutnya adalah mengungkapkan selengkap mungkin ayat-ayat al-Quran yang memiliki kecenderungan hukum kesejearahan. Dalam hal ini Baqir al-Shadr menegaskan bahwa mufassir maudlu'i tidak cukup hanya berdasarkan Mu'jam. Akan tetapi mufassir harus selalu membaca teks al-Qur'an berulang-ulang sekaligus kandungan maknanya.

Lebih jauh lagi konsep min al-Waqi ila al-nash, من الواقع إلى النص, tidak hanya berkonsentrasi pada al-Waqi (baca: realitas) dan begitu saja mengenyampingkan al-Qur'an sehingga seolah-olah tafsir tersebut bernuansa subyektif. Akan tetapi analisa realitas tersebut diposisikan sebagai pengkayaan modal bagi mufassir ketika berdialog atau menelusuri ayat-ayat terkait. Pembacaan realitas bukan untuk mendukung asumsi subekyektif mufassir tetapi justru untuk meningkatkan obyektifitas penafsiran karena mufassir dengan sikapnya mempersilahkan al-Qur'an untuk berpendapat sendiri dengan cara mengeluarkan sebanyak-banyaknya ayat ayat yang terkait. Langkah ini tentunya berbeda dengan yang dilakukan oleh Hassan Hanafi yang 
penafsirannya tematiknya lebih bernuansa subyektif (Syamsuddin, 2009).

Masing-masing ayat yang telah dikumpulkan kemudian dipahami satu persatu dengan bantuan tafsir tahlili. Mufassir maudlu' $i$ harus benar-benar memahami terlebih dahulu kandungan makna ayat al-Qur'an sebagaimana yang telah diungkap oleh tafsir klasik yang semuanya tersesusun secara tahlili, antara lain makna masing-masing kata. Setiap kitab-kitab tafsir pasti menjelaskan terlebih dahulu makna masing-masing kata atau lafadz ayat-ayat al-Qur'an. Dalam hal ini Baqir al-Shadr menekankan agar penafsir atau peneliti mempersilakan al-Qur'an berbicara sendiri tanpa ada campur tangan aktif dari peneliti.

Kata-kata dalam al-Qur'an ada yang memiliki makna tetap tidak berubah meski lintas zaman tetapi ada juga yang mengalami perubahan makna jika dihubungkan dengan pemakaian pada saat ini. Di sini dibutuhkan kehati-hatian dan ketelitian peneliti dalam menetapkan makna lafadz agar memegang teguh makna asal. Pemaknaan obyektif inilah yang ditekankan dalam metode maudlu'i. Menurut Baqir al-Shadr, sebagaimana yang dikutip oleh Baqir Bari, pemaknaan kata yang selalu dikondisikan dengan situasi sekarang tanpa memedulikan makna yang dipergunakan alQur'an akan menghasilkan makna yang menyimpang (al-Bari, tt). Dengan demikian peneliti atau mufassir maudlu' $i$ juga harus menguasai dan memahami makna masing-masing kata sesuai dengan yang dikehendaki oleh al-Qur'an. Artinya, bahasa yang digunakan al-Qur'an tidak identik dengan bahasa yang digunakan masyarakat Arab waktu itu. Dengan kata lain kajian bahasa menjadi penting sebagai sandaran awal penafsiran.

Selanjutnya dengan menggunakan munasabah alQur'an. Jika diibaratkan pakaian, maka munasabah adalah benang yang menyambungkan kain-kain yang ada (al-Zarkasyi, tt) Ilmu munasabah adalah ilmu yang didasarkan pada keyakinan bahwa al-Qur'an ibarat bangunan yang bagian-bagiannya saling menguatkan. Ia laksana kesatuan kalimat yang tidak bisa dilepaskan 
antara yang satu dengan yang lain. Ilmu ini pun sangat urgen karena berfungsi untuk menguji kesahihan struktur kalimat, dan ilmu ini menjadikan setiap bagian kalimat berkaitan dan saling menyempurnakan dengan yang lain. Hal ini kemudian menurut Subhi Shaleh menjelaskan bahwa adanya hubungan ayat-ayat alQur'an yang sangat kuat (Shaleh, 1968).

Asbab al-Nuzul pun menjadi penting setelah mufassir menemukan relasi dari setiap ayat. Karena al-Qur'an sendiri merupakan al-Muntaj al-Tsasqafi, meminjam istilah Nashr Hamid Abu Zaid, atau bina alInsaniyyah, menurut Baqir alShadr, maka tidak mungkin tidak akan terikat pada konteks kemanusiaan. Oleh sebab itu peristiwa serta latar-belakang dan konsdisi sosial historis masyarakat Arab menjadi penting untuk dijadikan pedoman dalam menafsirkan ayat-ayat al-Qur'an.

Perihal asbab al-Nuzul maka Baqir al-Shadr mengatakan bahwa ayat-ayat al-Qur'an terbagi menjadi dua, pertama, ayat-ayat yang diturunkan sebagai hidayah, pendidikan, tanpa ada sebab-sebab tertentu. Seperti deskripsi tentang hari kiamat dan kondisi orangorang yang akan mendapatkan nikmat dan mendapatkan adzab. $K e d u a$, ayat-ayat yang diturunkan dengan sebab tertentu yang menunjukkan pada turunnya ayat al-Qur'an. Seperti pernyataan yang membutuhkan jawaban pada waktu pertanyaan itu diajukan. Dan inilah yang dimaksud sebagai asbab al-Nuzul oleh Baqir alShadr. Adapun manfaat daripada ilmu ini adalah untuk mengetahui rahasia-rahasia pengungkapan alQur'an, karena teks al-Qur'an, memang, berkaitan erat dengan sebab-sebab tertentu (al-Shadr, 2005).

Setelah asbab al-Nuzul yang akan membantu penafsiran secara tematik adalah pemilahan antara ayat-ayat makkiyyah dan madaniyyah. Istilah ini sendiri bukanlah istilah yang diberikan oleh Nabi tetapi oleh para ulama tafsir (al-Shadr, 2005). Baqir alShadr pun meyakini bahwa pemisahan ayat-ayat makkiyahmadaniyyah ini, yang bersumber dari al-Tartib al-Nuzuli, mempunyai peran siginifikan dalam tafsir tematik. Karena dengannya mufassir bisa 
mengetahui tahapan-tahapan da'wah yang dilakukan oleh Islam melalui Nabi (al-Shadr, 2005). Tak pelak Baqir al-Shadr pun memberikan komentar terhadap kategori yang dibuat para setiap marhalah. Akan tetapi nampaknya Baqir al-Shadr tidak terpengaruh oleh para orientalis, semisal Theodore Noldeke (2000) yang membagi periode Mekkah/makkiyyah menjadi tiga periode dan madaniyyah menjadi satu periode dengan asumsi sastranya. Ia masih berpegang teguh pada konsep ulama Sunni yang membagi makkiyahmadaniyah menjadi dua periode saja. Adapun karakteristik daripada ayat-ayat makkiyah dalam pandangan Baqir al-Shadr, a. Ayat serta surat yang pendek disertai suara yang sama pada akhirnya;

b. Mengajak pada dasardasar keimanan, khususnya pada Allah serta hari akhir dan juga ilustrasi neraga dan surga, masyahid al-Qiyamah;

c. Dakwah tentang penegakan akhlak yang mulia dan konsistensi dalam melakukan perbuatan yang baik; d. Debat dengan masyarakat musyrik Mekkah;

e. Penggunaan kata "ayyuha".

Adapun karakteristik dari ayat serta surah madaniyah secara global mencakup:

a. Ayat serta panjangnya surat;

b. Perincian bukti-bukti serta dalil-dalil terhadap kebenaran agama;

c. Debat dengan ahul alKitab dan pelarangan terhadap mereka untuk berlaku berlebihlebihan dalam agama;

d. Perbincangan tentang orang-orang munafiq serta bentuk-bentuknya;

e. Perincian hukum hukum sosial;

Penggunaan teori ini menurut Baqir al-Shadr sangat penting, contohnya ketika berbicara tentang peperangan, alHarb. Dengan menggunakan teori makkiyah-madaniyyah dapat diketahui bahwa adanya peperangan sangat berhubungan erat dengan suatu sistem kedaulatan yang itu hanya ada ketika Rasulullah berada di Madinah, tepatnya setelah Hijrah (al-Shadr, 2005) Oleh sebab itu 
diketahui bahwa perintah perang bukan hanya berhubungan tentang agama an sich tetapi juga kedaulatan.

Dari rangkaian langkah metodis ini nampak bahwa Baqir al-Shadr menginginkan mufassir agar lebih obyektif dengan tidak serta meninggalkan horizonhistoris mufassir ketika akan memulai aktivitas penafsiran. Sehingga adagium min al-Waqi ila al-Nash bukanlah usaha untuk menundukkan teks pada realitas tetapi lebih kepada dialektika teks dengan realitas. Karena pada akhirnya ketika masuk pada upaya kedua, al-Tauhidi, mufassir disarankan untuk melakukan langkah-langkah yang sama persis dengan langkah tafsir tahlili namun tidak secara mendetail. Hal ini nampak dari tidak dijadikannya hadis sebagai rujukan utama setelah al-Qur'an akan tetapi hanya dijadikan sebagai tambahan.

3. Perbedaan al-Tafsir alMaudlu'i al-Tauhidi dengan alTafsir al-Tajzi' $i$ atau al-Tahlili Tafsir maudlu'i lebih kompleks dan lebih tajam dibandingkan dengan tafsir tahlili (analitis). Sebagaimana yang telah dikemukakan oleh al-Shadr tentang perbedaan antara tafsir maudhu'i dan tahlili yaitu, pertama, peran mufassir yang mempergunakan tafsir tahlili umumnya pasif. Pertama-tama ia mulai dengan membahas sebuah naskah al-Qur'an tertentu, dimulai dari sebuah ayat atau kalimat, tanpa merumuskan dasar-dasar pemikiran atau rencana terlebih dahulu, kemudian mencoba untuk menetapkan pengertian al-Qur'an dengan bantuan perbendaharaan al-Qur'an dan berbagai indikasi yang ada padanya dalam naskah khusus tersebut ataupun yang di luar itu.

Secara umum usahanya terbatas pada penjelasan sebuah ayat al-Qur'an tertentu. Dalam hal ini, peran teks serupa dengan si pembicara, dan tugas pasif mufassir ialah mendengarkan dengan penuh perhatian dengan pikiran yang cerah dan jernih serta penguasaan atas bahasa arab. Dengan pikiran dan semangat yang demikian mufassir duduk menghadapi a1-Qur'an dan mendengarkan dengan penuh perhatian peranannya pasif sementara al-Qur'an menonjolkan arti harfiahnya, si mufassir 
mencatatnya di dalam tafsirya sampai pada batas pemahamannya.

Berbeda dengan yang pertama, mufassir yang menggunakan metode maudlu'i (tematik) tidak memulai aktifitasnya dari naskah al-Qur'an, tetapi dari realitas kehidupan. la memusatkan perhatiannya pada sebuah subyek tertentu dari berbagai masalah yang berhubungan dengan aspek-aspek kehidupan sosial atua kosmologi, dengan menggunakan kumpulan hasil pemikiran dan pengalaman manusia tentang subyek tersebut, pertanyaan-pertanyaan yang diajukan dalam pemecahanpemecahan yang dianjurkan sehubungan dengan masalah tersebut, dengan jurang pemisah di antara keduanya. Setelah itu, ia kembali kepada naskah al-Qur'an, namun tidak dalam posisi sebagai seorang pendengar pasif dan seorang pencatat. la menempatkan sebuah topik dan masalah yang ada dari sejumlah pandangan dan gagasan manusia dihadapan alQur'an. Dengan begitu ia mulai sebuah dialog dengan al-Qur'an, di mana mufassir bertanya dan aQur'an memberikan jawabannya.
Dalam metode tafsir maudlu' $i$ mufassir mengkaji topiknya dengan menghubungkannya dalam batasbatas kemampuannya, dengan pengalaman intelektual manusia yang tidak sempurna sebagaimana yang diwakili oleh pandanganpandangan berbagai pemikir baik yang benar maupun tidak benar dengan menggunakan pemikiranpemikiran tersebut sebagai alat bantu untuk memecahkan masalah yang dihadapinya.

Kemudian kembali menyimpan hasil pencariannya, ia kembali kepada al-Qur'an, tidak sebagai pendengar yang pasif tetapi sebagi seseorang yang memasuki suatu dialog. Dengan semangat pencarian yang kontemplatif, ia bertanya kepada al-Qur'an; dimulai dengan ayatayat al-Qur'an mengenai tema kajiannya. Tujuannya di sini ialah menemukan pandangan al-Qur'an mengenai tema dan sampai pada satu kesimpulan yang diilhami oleh al-Qur'an, sambil membandingkannya dengan gagasan-gagasan dan pandanganpandangan yang berhubungan dengan tema tersebut. 
Dengan demikian, perbedaan mendasar yang pertama antara tafsir tahlili dan maudlu' $i$ ialah bahwa dalam metode yang pertama si mufassir pasif, pendengar sambil membuat catatan yang tidak demikian dengan metode yang kedua. Tafsir maudhu'i berupaya meletakkan warisan intelektual dan pengalaman manusia sebagaimana juga pemikiran kontemporer di hadapan alQur'an, untuk mencari pandangan al-Qur'an tentang subyek kajian yang dibahas.

\section{Selanjutnya al-Shadr} mengemukakan bahwa perbedaan kedua bahwa tafsir maudlu'i selangkah lebih maju dari pada tafsir tahlili. Tafsir tahlili membatasi dirinya pada pengungkapan arti ayat-ayat alQur'an secara terperinci, sementara tafsir tematik menuju pada sesuatu yang lebih dari itu dan mempunyai lingkup pencarian yang lebih luas. la berusaha mencari tata hubungan antara ayat-ayat yang berbeda, yang perincian masing-masing ayatnya telah disediakan oleh metode analitik, untuk mencapai kepada sebuah susunan pandangan al-
Qur'an yang utuh, yang di dalam kerangka kerja tersebut masingmasing ayatnya mempunyai tempat sendiri.

Dengan demikian, tafsir maudlu'i satu tahap lebih maju dari pada tafsir tahlili, dan bertujuan untuk sampai pada suatu susunan pandangan yang mewakili sikap al-Qur'an tentang sebuah tema tertentu dari berbagai ayat ideologi, sosial dan kosmologi. Keutuhan antara teks al-Qur'an dan pengalaman yang saling berdialektika ini pada dasarnya bertujuan untuk membela kepentingan kemanusiaan.

\section{Analisis Penafsiran Tematik Baqr Al-Shadr tentang Al- Hurriyyah}

Pada tahun $1381 \mathrm{H}$, Baqir al-Shadr menulis sebuah artikel dengan judul al-Huriyyah fi alQur'an di Majalah al-Adlwa yang akhirnya menjadi bab akhir dari karyanya al-Madrasah alQur'aniyyah. Secara metodis ia langsung mengutip ayat-ayat yang, menurutnya, relevan dengan kebebasan, Ali 'Imran [3]: 65, 1415, al-Jatsiyah []: 13, al-Baqarah [2]: 29 , dan 256. 
Dari pembendaharaan ayat al-Qur'an ini ia kemudian membreakdownnya dengan sub judul tertentu; 1) Kebebasan sebagai Perasaan Utama, 2) Batasan Kebebasan, 3) Kebebasan dalam Kebudayaan Barat, 4) Kebebasan ala Islam, 5) Kebebasan Internal Manusia, 6) Kebebasan Manusia dalam Konteks Masyarakat, 7) Kebebasan dalam konteks Perbuatan, dan 8) Makna Tidak Adanya Paksaan dalam Beragama (Baqir al-Shadr, 2005: 356-3640)

Sebagai seorang filosof tentunya al-Shadr tidak terlalu asing dengan teori kebebasan. Bahwa pada dasarnya kebebasan manusia adalah kemauan setiap pribadi manusia. Akan tetapi ia menyadari bahwa kebebasan individu itu tidak mutlak bebas. Dalam arti bahwa kebebasan itu akan terbentur dengan kebebasan orang lain.

Oleh sebab itulah kemudian ia merujuk pada teori serta aplikasi kebebasan yang ada di Barat. Karena, mau tidak mau, perkembangan teori disana sudah jauh berkembang dan mempunyai beragam bentuk yang jauh berbeda dengan Islam. Kebebasan dalam konsep Barat menurutnya adalah kebebasan yang dilandasai dengan kemauan seseorang dengan syarat tidak mengganggu kebebasan orang lain. Inilah yang kemudian melandasai pembentukan Hak Asasi manusia. Pada tahap selanjutnya ia kemudian membandingkannya dengan kebebasan dalam konsep Islam. Al-Shadr dalam hal ini mengutip Ali 'Imran [3]: 65 sebagai sebuah landasan kebebasan Islam yang didasari tauhid. Artinya dalam konsep Islam kebebasan manusia itu dibatasi dengan kewajiban manusia terhadap Tuhan, yang disebut dengan syari'at.

Namun konsep ini tidak akan berkembang kecuali seseorang sudah memiliki kesadaran atas kebebasan internalnya masing-masing. Kebebasan internal itu tiada lain adalah kebebasan yang berbeda dengan hewan serta kebebasan yang jauh dari hawa nafsu sehingga kebebasan itu menjadi kebebasan suci, al-Huriyyah alThahirah. Maka manusia disebut manusia apabila ia mampu mengelola kebebasan manusiawinya dengan tidak 
mengikuti hawa nafsu. Sebagaimana yang difirmankan oleh Allah dalam surah Ali 'Imran [3]: 14-15. Maka sebenarnya Islam itu membebaskan manusia dari segala kecenderungan dan ketergantungan makhluk Allah. Hal ini pun berlaku pada kebebasan manusia dalam konteks masyarakat yang harus selalu didasari dengan sikap tauhid. Dengan kata lain manusia itu akan bebas apabila ia mampu memebaskan dirinya secara internal dari syahwat dan secara eksternal dari sesembahan tuhan temporal.

Dalam konteks yang lebih luas, kebebasan manusia pun Allah berikan pada konteks eksplorasi Sumber Daya Alam serta segala sesuatu yang Allah ciptakan. Maka Khalaqa lakum ma fi al-Ardl Jami'a, wa sakkhara lakum ma fi al-Samawati wa ma fi al-Ardl Jami'an, adalah dua ayat yang melegitimasi bahwa manusia yang dibebankan oleh Allah sebagai khalifah bebas untuk bereskplorasi terhadap ciptaanNya dengan syarat bahwa, pertama, ia tidak dikuasai oleh hawa nafsu atau dibatasi dengan kebebasan internal dan kedua, ia tidak terobsesi dengan hal-hal yang bersifat duniawi atau dibatasi kebebasan eksternal.

Pada akhirnya al-Shadr pun mencoba menyentuh kebebasan dalam ranah agama dengan mengutip la ikraha fi al-Din. Dengan selalu berupaya mendialogkkan nilai moral ayatayat sebelumnya. Pada ayat ini ia mengatakan bahwa memang ada kebebasan seseorang dalam memilih agama. Akan tetapi disisi lain agama pun sudah menyampaikan bahwa petunjuk sudah lebih nyata dari pada kesesatan. Sehingga ketika ajaranajaran itu sudah disampaikan maka kebebasan individu lah untuk memilih apakah ia ingin mendapatkan petunjuk, al-Rusyd atau al-Ghayy.

Nampak dari hasil penafsiran Baqir al-Shadr pada judul ini ia lebih menggunakan alRa'y, nalar, tanpa melandasinya dengan metode tahlili. Tidak didapatkan konteks khusus atau asbab al-Nuzul dan ia pun tidak berupaya merekonstruksi ayatayat yang ia pilih dalam teori makkiyyah dan madaniyyah. Dan dasar-dasar pemilihan ayat pun nampak asbtrak karena ia secara 
langsung ditampilkan di awal. Walaupun pada akhirnya ada penjelasan secara konseptual yang dijabarkan pada setiap bab judulnya. Oleh sebab itu usaha yang dibangun secara metodis oleh Baqir al-Shadr dalam tafsirnya belum mampu diaplikasikan secara maksimal. Walaupun ia sendiri berupaya untuk menjaga dialektika antara ayat per ayat. Dalam istilah Gadamer, horizon penafsir lebih dominan daripada horizon teks itu sendiri. Sehingga hasil yang diharapkan pada obyektifitas belum maksimal dilaksanakan, bukan karena hasil penafsirannya tetapi metode atau langkah yang ia beberkan dalam al-Tafsir alMaudlu'i al-Tauhidi-nya belum bisa ia aplikasikan secara sempurna.

Namun secara keseluruhan konsep al-Shadr merupakan terobosan dalam wacana perkembangan al-Tafsir alMaudlu'i yang hanya berkutat pada pengumpulan ayat-ayat alQur'an tanpa disertai dengan dialog yang intens antara peristiwa faktual, al-Waqi, dengan ayatayat, al-Nash, tersebut.

\section{KESIMPULAN}

Sebagai seorang filosof, ahli ekonomi, ahli hukum, juga mufassir Baqir al-Shadr memberikan terobosan baru dalam konstruksi al-Tafsir al-Maudlu'i al-Tauhidi yang cenderung tekstual dan baku. Dalam konsep tafsirnya al-Shadr kemudian menjadikan min al-Waqi ila alNash sebagai asumsi dasar bahwa sebuah tafsir tematik harus dimulai dari peristiwa atau kondisi faktual baru kemudian dikembalikan kepada al-Qur'an yang darinya seorang mufassir mampu mengambil esensi serta teori al-Qur'an yang berhubungan dengan peristiwa tersebut. Dengan dijadikannya al-Waqi sebagai sebuah pedoman awal bukan berarti ia ingin menundukkan alQur'an pada al-Waqi atau sebaliknya justru ia ingin membuat seorang mufassir agar mampu berdialog dengan alQur'an.

Pada langkah metodisnya Baqir al-Shadr pun menyadari bahwa tafsir tematik tidak bisa lepas dari pemaknaan kosa-kata, asbab al-Nuzul, munasabah alAyat dan teori makkiyahmadaniyyah. Akan tetapi secara 
praksis metode yang ia bangun sendiri belum bisa dilakukan secara maksimal, setidaknya tergambar dari pembahasannya tentang al-Huriyyah fi al-Qur'an, yang masih memperlihatkan subyektifitas mufassir daripada obyektifitas al-Qur'an.

\section{DAFTAR PUSTAKA}

Al-Farmawi, Abd al-Hayy. (1977) Al-Bidayah fi Tafsir al-Maudlu'i.Mesir: Maktabah Jumhuriyah. . Mu jam al-Alfadz wa al-A'lam al-Our'aniyah. (1968). Kairo: Dar al-`ulum.

Al-Shadr, Baqir. (2005). al-Madrasat al-Qur'aniyyah. Qum: Markaz alAbhats wa al-Dirasat al-Takhoshshusiyyah.

Al-Zarkasyi, Badruddin. (tt). al-Burhan fi 'Ulum al-Qur'an .

Djalal, Abdul. (1990). Urgensi Al-Tafsir al-Maudlu'i Pada Masa Kini. Jakarta: Kalam Mulia.

Ibrahim, Mursyi. (1980). Dirasah fi al-Tafsir al-Maudlu'i i. Kairo: Dar alTaufiqiyyah.

Noldeke, Theodore. (2000) Tarikh al-Qur'an terj. Farid Yaris Syafali. Newyork: Dar Nasyr George.

Permana, A. K. (2020). Nuansa Tasawuf dalam Surah al-Fatihah: Analisis Mafâtîh al-Ghaib Karya Fakhruddîn al-Râzî. Jurnal At-Tadbir: Media Hukum Dan Pendidikan, 30 (1), 67-92.

Shaleh, Shubhi. (1968). Mabahits fi 'Ulum al-Qur'an. Beirut: Dar al-'Ilm al-Malayyin, cet. V.

Syamsuddin, Sahiron. (2009). Hermeneutika dan Pengembangan Ulumul Qur'an. Yogyakarta: Nawasea Press. 